IMRe JózSEF BALÁzs

Universitatea Babeș-Bolyai

\title{
Hungarian Stories of the Regime Change: Voices and Perspectives
}

Around 2010, two decades after the regime changes in East Central Europe, discussion of the political and social changes reached an important psychological landmark: a generation with no personal memories of the Communist period entered the public space and began to give voice to the post-communist agenda of its own. Intergenerational dialogue gained increasing importance and, along with the "archival boom" in the region, provoked established approaches to the recent past. In Romania and Hungary, access to the secret police archives was delayed and limited, but when they eventually were opened new documents profoundly transformed the perceptions of the cultural field under Communism and the related narratives of the older generations from the 2000 s onwards. Competing narratives of the regime change have now emerged that are also conditioned by a great variety of social trajectories: many enjoyed the benefits of the new political environment, but there were many whose social status decreased and had to face serious difficulties. All these made an impact on how one tells the story of the regime change and, in the field of literature, influenced what kind of narrative voices have emerged and how recent literary texts are scaled. In this paper, I will focus on Hungarian literature written in Romania to demonstrate that dealing with the recent past became a way of articulating a wider range of issues in this area, including power relations, individual responsibilities, and failed attempts to understand and to communicate. 
There are certain traits of contemporary Hungarian fiction dealing with the past that let literary scholar Edit Zsadányi identify a specific type of narrative that has recently emerged: one that reinterpreted established stories of the regime change, stories that were legitimized by political authorities in various ways. Reflecting a widespread focalization strategy she pointed out that authors like László Garaczi, Endre Kukorelly, György Dragomán, Ferenc Barnás and Szilárd Borbély, who narrate the past from a child's perspective, give voice to the 'subaltern' and this gives wider credibility to the narrative, additionally allowing to associate the postcolonial mindset with postcommunist experiences. This may result in a methodology that approaches Eastern European postcommunist experiences in a wider, planetary context instead of a historicized and localized analysis (Zsadányi 175).

The above mentioned focalization strategy is present also within a more specific corpus of Hungarian literature-in texts written by Hungarian minority authors living in Romania and dealing with the regime change of December 1989. The key difference between Hungarian literary works dealing with the regime change in Hungary results from the difference between the two political shifts. While the regime change became a central topic for a new generation of Hungarian writers in Romania, it was not the case in literature written in Hungary. In the latter case, the soft dictatorship of János Kádár allowed authors to represent political changes only as a background that is, in the final account, secondary to the story of their transition from adolescence to the life of a grown-up person, see the prose of László Garaczi as a good example. It is instructive that contributors to a 2009 conference on the literature of 1989 concluded that "the" novel of the regime change still awaits to be written. In contrast to the by-and-large peaceful changes in Hungary, Romania witnessed a sudden change perceived by the population as a "revolution." There were fights on the streets, and many of the anti-communist protesters were killed during the events. The sense of a violent ending of the regime was highlighted also by the much-debated execution of the leaders of the totalitarian regime, Nicolae and Elena Ceauşescu. This is why for authors belonging to the Hungarian ethnic minority from Romania (of approximatively 1.5 million people at that time), discussing the events of the regime change became a primary opportunity to voice a set of experiences that include the sense of claustrophobia, liberation, grief, hope and disillusionment. In literary narratives of Romania's Hungarian authors, the contrast between the shifting realities and regimes tends to be sharp and occupies the central stage, the historical clash being more dramatic.

Hungarian novels of the postcommunist era frequently address the theme of fluid and dislocated identities. Such identities are partly the results of a con- 
frontation with the "other" and with a number of alternative narratives. As a part of identity construction, territoriality also becomes a relative and fictional notion throughout these stories and this is an aspect that results in an increasingly reflexive character of these narratives, a character that questions its potential to engender fixed, stable and atemporal identities.

Within the multilingual literary scene in Romania, where Romanian, Hungarian and German language literary cultures coexist, Deleuze and Guattari's perspective of "minor literatures" provides a particularly fruitful approach. ${ }^{1}$ In Hungarian and German literature from Romania, the "regime change" transcends precise territorialities: these literatures are intimately linked to the wider context of Hungarian and German cultures and texts are often constructed with a wider East European system of reference in mind, or in an even more abstract way that allows readers to approach such novels and short stories as "planetary" phenomena. The German-language writer originally from the Banat region, Herta Müller, for instance, or the major Hungarian author Ádám Bodor from Transylvania, who both left Ceaușescu's Romania in the 1980s, are just two outstanding examples of writers who augmented the relevance of minority perspectives in their attempt to challenge the totalizing and totalitarian narratives in the context of the Communist regime of Romania, and in fact, they pointed out the relevance of "minor" approaches in a broader context. On a world scale, all identities become fluid, following the pattern of minor literatures. As Jing Tsu suggests, all future literary studies should take into account this multitude of perspectives:

Whether the present new scale of literary studies can reach its purported audiences, be they distant cultures, minor literary traditions, or parallel world histories, depends on what the "world" means. The sum of its parts, as a spatial setting, a global genre, a new connectivity, an open process of discovery, or the latest contender in canon making, world literature refracts a variety of desires for the agenda of future literary studies. (158)

This could be a vision that records the nonlinearity of history, a vision that is ready to address a literature organized under the form of nodes and networks with changing configurations (Cooppan 196), and also a vision of dialogue between different generations or different East Central European cultures.

1 See Gilles Deleuze and Félix Guattari. Kafka: Toward a Minor Literature. Trans. Dana Polan. Minnesota: University of Minnesota Press, 1986. 
Discussions about the representations of regime change in Hungarian literature highlighted the question of great expectations and disillusionment, and also some normative approaches expecting broad, panoramic descriptions within the literary texts. These approaches missed, however, precisely the new, emerging types of "minor" narratives that offered a view from below, as a microhistorical representation of events.

In what follows, I will provide a brief analysis of the narrative strategies of three Hungarian novels that were published around the twentieth anniversary of the regime change. All three-Andrea Tompa's A hóhér háza (The Hangman's House), Sándor Zsigmond Papp's Semmi kis életek (Little Lives), and Zsolt Láng's A föld állatai (Animals of the Earth) - are connected to the Romanian events but have been influential in the entire Hungarian literary scene. The analysis focuses primarily on the perspectives these books offer on social and political changes. The three novels are not only thematically linked: I claim that they form part of a literary paradigm that originates in a trilogy of eminent Hungarian author, Ádám Bodor.

Bodor's Sinistra körzet (1992; translated to English as The Sinistra Zone) was a major success in the 1990 s both in Hungary and in the Hungarian literary field in Romania, followed by Az érsek látogatása (1999; The Visit of the Archbishop) and Verhovina madarai (2011; The Birds of Verkhovina). These novels' literary style that combine grotesque minimalism and magical realism deeply influenced a cohort of younger authors like György Dragomán, Sándor Zsigmond Papp, or Gábor Vida, so much so that some critics identified a "post-Bodorian" literary current (Bányai 95-102). Although Bodor's novels systematically dismantle simplistically direct, referential readings, they provide undoubtedly relevant guidance for the interpretation of recent decades in Eastern Europe. The novel sequence provides insight to the regime change through a precise and distanced description of the evolution of power relations. While the power structure in The Sinistra Zone is direct and evident, possessing a military nature (that corresponds to the power formation of the period immediately preceding the regime change), The Visit of the Archbishop refers to a process of power transfer where the changes are superficial, non-essential, and the hierarchy of power has not changed in a profound manner; to this, The Birds of Verkhovina adds a completely contemporary, diffuse form of power, which is elusive, partly economic, but sometimes also functioning at a declarative, unsupervised level, as in the case of Anatol Korkodus's "Water Brigade." In Verkhovina, power lies somewhere far away, in the background-and yet its presence is manifest. Because of its distance, the rebellion against local power structures is hopeless: if the source of power cannot be located, it cannot be targeted. This experience 
corresponds broadly to the one connected to contemporary, transnational, intercontinental power structures. Freedom is delusive in this context-there seem to be no obstacles, but it is quite difficult for the characters to make the necessary moves to experience it. Bodor thus creates a sort of anthropology of the regime change, discussing also the unwanted continuities of the process.

The novels of Tompa and Láng, in contrast, do not extend far beyond the turning point of the regime change; the Little Lives by Papp is an exception among the three in this respect. But all three adopt a perspective close to Bodor's Verkhovina. The differences between the narratives do not result, therefore, exclusively from the choice of the location for the backward glance, but also from the way these novels deal with the "latent" knowledge about the postcommunist decades.

\section{The Hangman's House: Stories from the Golden Age}

In 2009, Romanian screenwriter and director Cristian Mungiu released a series of short films, Amintiri din Epoca de Aur (Memories of the Golden Age). The "golden age" syntagma was originally used by Ceauşescu with reference to the last 15 years of his regime and it appears in the subtitle of Tompa's novel as well. Both Tompa and Mungiu belong to a generation born at the turn of the 1970s, who have heavily invested in capturing the world before the regime change. Mungiu's films are based on urban legends and oral histories that circulated in Romania in various versions. Some pieces are anecdotical, others set in a mythical tone. Similarly, other artists and writers depict the "golden age" in great variety: some use a minimalist style, others create ironic distance, sometimes the style is casually direct, sometimes shocking. However, there is a recurring feature that links the works of arts of this generation: they all are "histories from below." Tompa's novel is not an exception.

The Hangman's House depicts life in a major city in Romania, Cluj-Napoca. The protagonist is a teenage girl who has a "fresh" perspective on the absurdities happening in the 1970 s and 1980s. Through the story of a single family, it opens windows to Romanian society, but since the emphasis is placed on the revolutionary events, this novel becomes indeed a book of the regime change, rather than simply a book about everyday life during Romanian Communism. Flashbacks of family history are framed in the context of Christmas Eve of 1989: this structural choice suggests that there is hope. There are also small, irrational miracles within the story - the demolition of the old buildings in Cluj-Napoca spares the Dohány Street family house, which plays an important role in the narrative. The house remains a safe place where the protagonist may return to at 
any moment. Vitality flows from the story, obviously connected to the main character in the book, a teenage girl situated in the midst of exploring the world, when everything seems possible. Alcoholic men, demolished houses, dismantled small communities, broken marriages bring balance into the narrative.

The structure of the book is fragmentary: the short chapters try to capture a single small theme, figure, or phenomenon by jumping back and forth between the decades of the twentieth century. Each chapter consists of one single long sentence that gives special dynamics to the text. Zooming in on each of the figures, events and relationships, results in the second half of the book invoking in the reader a sense of familiarity with regards to the created world of the characters coming from different regions of Transylvania. Through individual stories, Tompa offers an intriguing description of the power structures and of the possibilities to move within the field of power.

The interior and exterior connections of the family portrayed in the novel have many aspects: the family is connected to power, but not quite strongly (within the family there are secretaries of local Party branches, but also "class enemies"), they occupy a variety of power ranks, and the father's "decadence" means decadence in the social sense as well. The family knows the world inside and outside the counters of socialist shops (the mother is the manager of the central store), and is confronted with identity problems (the more conservative Szekler family line is combined with a socially mobile Jewish identity). The girl of outstanding talent and literary sensitivity must be able to resist the shift to a Romanian school environment and must be at the same time an insider of adult games and of teenage rituals. Teachers, actors, poets and family members are also involved in processes that lead from forms of "resistance through culture" (such as jazz culture, alternative theatre performances) to actual political dissidence (carrying messages to and from pre-revolutionary Timisoara). Sexuality remains in this context rather a source of unquantified desire and energy, instead of a materialized event.

Andrea Tompa's novel connects the outside and inside worlds, explains and interprets these in floating sentences, and presents the basic stories that determined the existence of average people in Cluj, from the twenties and thirties to the regime change in 1989. The novel connects the inexperienced character of a teenage girl to historical events, and through this focus gives voice to a type of subaltern people in the Romanian Communist regime. 


\section{Little Lives}

"I want to tell the story of a place, not a person," reads the motto of the novel by Sándor Zsigmond Papp, taken from Gide. For Papp, space is a metaphor for representing human relationships, and apartment houses are paradoxical places of co-existence: complete intimacy and seclusion is impossible within such spaces. Secrets cannot be kept, and obscure details of everyday life provoke the curiosity of the neighbours. This spatiality recreates in fact the atmosphere of Communist everyday life where agents of the secret police had access to the details of "little lives", and secrets tended to become political in the sense that they could be used for political purposes by the power structures. A main character of the novel, one of the winners of the regime change, for instance, is a former secret police officer. He becomes a smart entrepreneur who takes part in the postcommunist everyday life under a different name. The story of the "turn" is accessible through such characters' lives. In this respect, in Little Lives representations of the regime change are more direct, non-metaphorical as compared to Bodor's trilogy.

The main point of the book seems to be that the desires of liberation were not strong enough within the society. In this respect, Papp's novel to a greater extent remains in the realms of Bodor's world than The Hangman's House. In this world one needs to accept the rules of the game and avoid confrontation. At the same time, the anti-heroes of Papp's novel have more glamor and hedonism in their lives than Bodor's characters. Papp's humorous but sometimes bloody episodes can be situated somewhere in the vicinity of Hrabal's stories.

For entire generations, freedom came "too late," as the novel suggests. Jani Rot, the mentioned secret police officer, still in power, says most sensitively, "there are those for whom the freedom came too late... Freedom ... They don't even know who to hate" (Papp 301). Obviously, this is the motive of the "failed regime change." But it is important that Papp does not transfer this failure to "others," but rather concentrates on individual responsibility: the novel repeatedly refers to the power of will, desire, and diagnoses an attitude that is unable to transcend the trap of not wanting to remember, but unable to forget. This means that within the world of the novel, the regime change should occur first of all within the minds of the characters, and the tragedy of these anti-heroes is that they are unable to actively deal with the past.

The novel directly addresses the issue of rival narratives about the regime change, contrasting mainstream Western discourses with local experience. The Western approach is represented by a German film crew wanting to produce a documentary film about the 1989 Romanian events. The memory politics of transition is reflected through the dialogues between the film crew and 
Kalcsek, a tenant in the apartment house. Kalcsek identifies romanticizing and colonizing expectations manifested in the questions of the director:

It was difficult to decide whether or not to talk about this at all, but the director ... was so eager to preach the German people's interest in the story, as if all Germans had already been knocking at the door of Kalcsek.... But you are expecting theory, not answers, he finally told the interpreter. (Papp 261-262)

According to Kalcsek (and through him, according to the novel), the story of the regime change cannot be cut short (there are only forty minutes at the disposal of the filmmakers), because it is precisely the micro-details that are the most important. So the "real" regime change movie is the novel itself, with its own little stories. What the director can show through the movie will, of course, have a much different, more compact effect: we can see here that the positive image of the regime change fits in with the expectations of some kind of Western propaganda machine. The market-expanding logic of the West in the novel tries to shape the narrative according to its own interests.

In Kalcsek's version, the German film crew members have freedom in their blood, but they are also incapable of actually connecting to those who are trying to imagine and mobilize their freedom. Their questions are simplistic and sensational, and they are waiting for confirmations of their preconceptions and previously elaborated versions. Kalcsek and the others, on the other hand, do not want to be involved in legitimizing such narratives. They search for alternative versions that are much harder to describe, and that remain fragmentary, despite the four hundred pages of the novel. Thus, incompleteness itself, together with the richness of the episodes, is the answer that Papp offers in his novel to the question of narrating the regime change through his poetics and reflexivity. It is in this precise episode that the 'subaltern' narrative directly challenges the dominant, politically legitimized plot of a master narrative.

\section{Animals of the Earth}

Animals of the Earth appeared as the fourth and closing sequence of Zsolt Láng's novel series Bestiarium Transylvaniae in 2011. It is located at an intersectional point of the oeuvre. The earlier volumes of the series dealt with events that had occurred much earlier, but Láng had a small novel entitled Perényi’s Liberation, which dealt with workings of the Evil in the world in the days of the Romanian 
revolution, and also with the myth of pure conception. The figure of comrade Dunea/Dulea, the local Party secretary also connects the two novels.

If, in the previous volumes of the trilogy, the temporal distance separating us from the narrated events allowed us to read them as historical novels (or pseudo-historical novels), for Animals of the Earth, the essence of provocation is precisely whether we can accept the narration of the recent past as a historical novel. The former Bestiary volumes were evidently linked to the meta-historical line of the prose of magical realism, but in the case of the recent past, it is necessary to create a distance, a level of reflection that can produce similar effects.

The novel achieves this effect by operating a specific mirror structure: the stories of the individual characters in the novel intersect and reflect on each other, and render each other's validity uncertain. We hear the voices of many potential narrators, and we get access to their thoughts-sometimes a high school student named Bori, sometimes a rat of extraordinary size and intelligence, sometimes another animal, and sometimes an officer of the secret police takes on the narrative voice. Stories and perspectives relativize each other, even though Bori's perspective fits the story in a more decisive way.

The animal figures "say" that some of the characters in the novel are projections of Bori's dreams ("On the roof, there stood a white dove with a human face, and she barely looked up, he knew somebody in the house was dreaming about this white dove"). The main character, as she says, is not interested in the truth of the statements, but in the overall interplay of the statements.

The term "animals of the earth" here does not refer so much to animals that live on the earth, but literally to animals that live in the ground or underground-in canals, basements, underground cavities. The underground world can be read in the novel as the projection of the subconscious, the inverse or mirror image of the above world, from which the intelligent rat observes the context of the order of the human world, easily seeing through rational human logic. Bori is "immersed" in this underground world twice, and in both cases returns to a transformed order when she emerges. On the first occasion, she enters the basement of her school where she finds historical objects, while, by contrast, what happens on the surface is arbitrarily rewritten history, a class that has nothing to do with factual history of the country. On her second descent, Bori walks through the city's sewerage system and faces a completely changed world when she comes to the surface-she witnesses the revolutionary transformation itself. The whole scene is "unbelievable" for her in some way, but Zsolt Láng's representation of the regime change is also reminiscent of the strategy of Little Lives: to approach abstractions from the perspective of the ordinary, the material. 
The peculiarity of Láng's novel is that it attaches great importance to imagination, which enables the creation of its own alternative (even underground) worlds, while also reproducing the same imaginative games in a parodistic register when anyone (the rat or the secret police officer) can be a creator of alternative worlds. The novel leaves open the possibility that we read a bluehaired rat's novel about the regime change.

The novel ends with a reflection on the nature of "acting in the name of eternal change" or "resilient immobility", on the other hand, and shows the superficial, temporary nature of change. At the same time, the text does not wish to become a novel of post-totalitarian depression, and considers returning to the "three days underground" immediately preceding the regime change, in order to find the need for rebirth. Although the final volume of the Bestiary series is only remotely connected to the earlier volumes, the title of the series still inserts this change of political narrative into a broader discussion of history and the nature of stories. In this way, Láng also claims what Tompa does: the nature of the historical turns cannot be understood without their history. In Láng's text, moreover, this becomes a meta-circumscription, where storytelling itself is relativized by the multiplication of storytelling modes. The phrase Bori thinks of as she walks through the city is probably the most memorable phrase in the novel: "Where does this present grow from, if no one knows its past" (Láng 219). The structure of the trilogy suggests that history is a constantly reconfiguring narration, and the more recent the narrated events are, the more uncanny the uncertainty referring to past events can be.

Láng's novel offers its own response strategy to the unfamiliarity of the past, as do the novels by Andrea Tompa and Sándor Zsigmond Papp, when they look back and forth in time from the perspective of posteriority. Their point of view is broadly in line with what I referred to as the Bodor paradigm, but at the same time, all three authors are extremely conscious of where they cut the threads of their stories, creating different effects of optimism and of disillusionment through simple narrative techniques.

Based on the overview of the three novels, I would argue that the type of narrative that configures "histories from below" in the postcommunist period is present also within the spectrum of Hungarian literature from Romania, but it tends to gain a specific functionality. Papp's novel, as I have shown, highlights the individual capabilities for freedom, and therefore individual responsibility. Láng and Tompa end their stories when they reach a moment of hope, of liberation, suggesting that all posterior lines of events are concentrated within those moments. Those inner, mental states serve as models for all future attempts for liberation, and the subsequent decades cannot overrule those individual 
potentialities. This point seems essential also within the intergenerational communication context that I described in the opening paragraph of my paper. Communicating the unfamiliar set of experiences to another generation needs to start, as it seems, from a point where these experiences are unfamiliar also for the narrative I-this is how a child's or a teenager's perspective becomes functional through such narrations.

The conclusion of my investigation goes in line with Papp's novel: history in the novels of East Central Europe is not to be created along major narrative lines. Official, politically promoted interpretations of Eastern European regime changes began to show their weaknesses during the last decades, their lack of a universal value. The possibility of literature lies in the fact that it is capable of telling stories that are not master narratives of a whole age, but through their relativizing narrative techniques they can create alternative interpretations that move closer to everyday, individual experience.

\section{| References}

Bányai, Éva. “The Space Concepts as Intercultural Experience in Contemporary Hungarian Prose." Acta Universitatis Sapientiae, Philologica 3.1 (2011): 95-102. Bodor, Ádám. Sinistra körzet. Budapest: Magvető, 1992;

Bodor, Ádám. Az érsek látogatása. Budapest: Magvető, 1999.

Bodor, Ádám. Verhovina madarai. Budapest: Magvető, 2011.

Cooppan, Vilashini. "World Literature between History and Theory." The Routledge Companion to World Literature. Eds. Theo Dhaen, David Damrosch and Djelal Kadir. London: Routledge, 2013.

Láng, Zsolt. Bestiárium Transylvaniae IV, A föld állatai. Bratislava: Kalligram, 2011.

Papp, Sándor Zsigmond. Semmi kis életek. Budapest: Libri, 2011.

Tompa, Andrea. A hóhér háza. Bratislava: Kalligram, 2010.

Tsu, Jing. "World Literature and National Literature(s)." The Routledge Companion to World Literature. Eds. Theo D’haen, David Damrosch and Djelal Kadir. London and New York: Routledge, 2011.

Zsadányi, Edit. "Voicing the Subaltern by Narrating the Communist Past through the Focalization of a Child in Gábor Németh's 'Are You a Jew?' and Endre Kukorelly's 'The Fairy Valley.' Postcolonial Europe? Essays on Post-Communist Literatures and Cultures. Eds. Dobrota Pucherová and Róbert Gáfrik. Leiden/Boston: Brill/Rodopi, 2015. 


\section{| Abstrakt}

IMRE JózSEF BALÁzs

Węgierskie historie o zmianie ustroju. Głosy i perspektywy

Narracje o zmianie ustroju w literaturze węgierskiej zyskały nowy charakter około 2010 r., po dwóch dziesięcioleciach postkomunizmu. Artykuł analizuje strategie narracyjne powieści przedstawiających ten temat, pokazując ich tendencję do przyjmowania mikrohistorycznego punktu widzenia. Omówione zostały również powieści napisane przez autorów wywodzących się z mniejszości etnicznych, takich jak Ádám Bodor, Andrea Tompa, Sándor Zsigmond Papp, Zsolt Láng, którzy w swojej prozie opisują dramatyczną zmianę ustroju, jaka miała miejsce w Rumunii w 1989 r.

Słowa kluczowe: mikrohistoria; mniejszość; postkomunizm; zmiana ustroju; subaltern

\section{| Abstract \\ IMRE JózSEF BALÁZs \\ Hungarian Stories of the Regime Change: Voices and Perspectives}

Regime change narratives in Hungarian literature gained a new type of consistency around 2010, after two decades of postcommunism. The article analyses narrative strategies of novels written about the regime change, showing their tendency towards a microhistorical approach. The discussed novels include works by such minority authors as Ádám Bodor, Andrea Tompa, Sándor Zsigmond Papp, Zsolt Láng, who represent in their novels the dramatic regime change that took place in Romania in 1989.

Keywords: microhistory; minority; postcommunism; regime change; subaltern

\section{| About the Author}

Imre József Balázs is an Associate Professor at the Department of Hungarian Literature at Babeș-Bolyai University, Cluj, and editor of the cultural review Korunk. His research interests include twentieth-century and contemporary Hungarian literature, minority cultures, avant-garde and socialist realism. In 2006 he was awarded 
the Arany János Prize for Young Scholars by the Hungarian Academy of Sciences. His major publications include: The Avant-garde in Transylvanian Hungarian Literature (2006, 2009), The New Centre: Tendencies in Contemporary Literature (2012). He has recently completed a monograph on the early works of Tibor Déry (2019). E-mail: lutraro@yahoo.com 
